\title{
The Philosophy of Work-Based on Four Stories
}

\author{
Rongrong Zhou \\ Department of Retrial, Shandong High People's Court, Ji'nan, China \\ Email: rongrong8799@126.com
}

How to cite this paper: Zhou, R. R. (2016). The Philosophy of Work-Based on Four Stories. Open Journal of Philosophy, 6, 436445.

http://dx.doi.org/10.4236/ojpp.2016.64041

Received: October 17, 2016

Accepted: November 14, 2016

Published: November 17, 2016

Copyright $\odot 2016$ by author and Scientific Research Publishing Inc. This work is licensed under the Creative Commons Attribution International License (CC BY 4.0).

http://creativecommons.org/licenses/by/4.0/

\begin{abstract}
Work helps us live a good life. "The Hungry Ocean" told us about the reason, value and compensation of work. "The Devil Wears Prada" taught us dramatic changes would appear when you chose a job. "Something Borrowed" is a great story of finding what you really want. "The Perfect Mile" helps us set up a goal and be ourselves. The four stories help us better understand the philosophy of work.
\end{abstract}

\section{Keywords}

Work, Value, Compensation, Good Life

\section{Introduction}

Everybody has to work to live a good life. Meanwhile, different work shapes different characteristic by adjusting one's framing schema and analysis of the world. This happens usually without consciousness. People use their freedom to choose a proper work, while the work selects appropriate people. To some extent, people interact with the environment by working. Work has mutual effect on internal challenge of a person and the external change of the world.

\section{The Hungry Ocean}

While steaming, the passage of time is measured in distance rather than hours, miles being more powerful than so many sweeps of the second hand. And with the exception of standing watches, the crew and myself are seldom aware of the time of day. An experienced crew member never asks "When will we be there?" but instead might inquire "How many more miles?" At sea, I am almost never cognizant of what day of the week it is, but am keenly aware of how many days must pass to bring the next full moon, the concept of time twisting to meet what is meaningful.

-The Hungry Ocean, p. 102 (Greenlaw, 2000) 
In the book "The Hungry Ocean", the author told us about her "story of a thirty-day sword fishing voyage aboard one of the best-outfitted boats on the East Coast, complete with danger, humor, and characters so colorful." She was the captain and during the trip they took the adventure at sea, prospecting the future and accomplishing difficult missions. Her work was a trip. The purpose is to enjoy the trip.

\subsection{The Reason of Work}

People have to work, but there must be some reasons. Most people work to fulfill life needs. Maslow's hierarchy of needs contains 5 tiers, which are physiological, safety, love/belonging, esteem and self-actualization. In order to fulfill the physiological and safety needs, people work to get money to feed an individual, support a family or sustain a community. Volunteer work is an exception.

To satisfy love/belonging, esteem and self-actualization needs, people work to achieve accomplishments for higher reputations, higher social status, or just for fun. They work to get social recognition and earn a decent life. Different jobs have different values, but all of them are respectable.

In this capitalized society, work, social status and money is a common label to evaluate a person. When a person becomes old, he/she probably regrets that his youth was dedicated to work and lost the opportunity to enjoy the nature, change of seasons, arts and music, which may not enrich our pockets, but will fulfill our hearts. But when one was young, pressures comes from the society. The normal work age is after graduation year of school until retirement. People often retire at 60 , during more than thirty years we are devoted to work.

\subsection{The Value of Work}

Carl worked quickly, with an economy of motion. As the circumference of the gear on the spool neared its maximum capacity, I wondered what more I could find for Carl to do to keep his mind on business and off harassing Peter for the next few days. Once fish started coming aboard, the problem would take care of itself. Carl would be too busy working even to throw Peter a dirty look. (The Hungry Ocean, p. 111).

Aristotle once observed: "Pleasure in the job puts perfection in the work." (Taylor, 2012). Different jobs have different social functions, but they all create valuable goods, tangible or intangible. For example, farmers produce corns and wheat by planting in the land; business people exchange goods and transfer wealth through diverse transactions; lawyers provide legal services by applying their knowledge and wisdom in daily life; doctors help patients recover from miserable diseases. By working, people forget time and duration but to engage in solving problems and overcoming difficulties, like Carl in the novel. Demonstration and dedication thrives work to a booming level, surpasses tedious repetition but reaches the eventual spiritual pleasure.

A person has the feeling of surpassing tedious repetition in work, because he/she has the individual intellectual creation through working, which adds value to the product. In addition, by collaborating with colleagues, the worker may absorb innovative ideolo- 
gies to refurbish his/her perception. A person with passion and patience will better experience the pure pleasure during daily breathtaking sunsets, rather than complaining a faded moonlight.

\subsection{The Compensation of Work}

The powers that be are known by fishermen to be somewhat whimsical in their doling out of good and bad, which accounts for our general distrust of any situation that seems remotely copacetic. Captain and crew often tiptoe around as if walking a thin line, afraid of doing anything that might upset some precarious balance and tip the scales from stability to doom. The majority of fishermen have learned the hard way not to boast, gloat, or even mention a pleasing situation for fear of jinxing themselves, summoning a flood tide of misfortune. (The Hungry Ocean, p. 195).

Once a person starts working, he/she follows a schedule or a plan to divide difficult tasks into everyday routine and keep his/her own pace in dealing with pieces of assignments. Wages, salaries or bonus is given to employees as compensation. Promotion may also be a kind of incentive measure. Almost every employer has an evaluation and growth system designed to encourage employees for making more profits. Compensation may also be a weighing factor when people choose their careers.

Workers' compensation is a form of insurance providing wage replacement and medical benefits to employees injured in the course of employment in exchange for mandatory relinquishment of the employee's right to sue his or her employer for the tort of negligence. The trade-off between assured, limited coverage and lack of recourse outside the worker compensation system is known as "the compensation bargain." Even though wages vary between different jobs, all the employees enjoy a minimum amount of salaries to sustain a decent life.

\section{The Devil Wears Prada}

Works are diverse, however for a person it maybe the whole world. What makes a good work? What is the standard for a person to choose the right job? How do they make the evaluation? What are the principles that are vital for healthy atmosphere at office?

When asked about the question "what jobs you choose depends on what kind of life you want to live", I cannot stop thinking another novel, The Devil Wears Prada (Weisberger, 2004). This story is about a girl called Miranda, who graduated as a journalist major and found a job in a fashion magazine. She used to wear grandmother's sweater, dingy shoes, and two-penny make-ups. After she was admitted to the position as boss's assistant, she decided to change from a weird animal to a modern "Chanel girl". The boss, who is a sophisticated lady wears Prada, was the queen of this magazine, and represents fame, priority and wealth. When choosing this position, Miranda started to live a luxurious life. Her boyfriend who was a baker fell that she went too far way that they had no common topics. She witnessed the fights among business people, the masks they wore, and the lies they to; $\mathrm{d}$. She fell exhausted of this kind of faking life. One day the boss called her and she did not answer, but instead throw the gorgeous cell phone 
into the spring pool. She changed over to the normal life style, and found a measured job in a small company.

When choosing a work, people choose a development environment. Once fixed in a position, a person becomes a member of a community, whose social function is marked according to the occupation. Different choices create different social labels. That is why Miranda in the novel changed a lot. She changed according to the environment. I have the same feeling when I was an intern in a big Chinese law firm. When I walk into the grand hall and step into the transparent elevator, suits and dresses replaced the casual clothes; urbane and aggressive manner replaced the mild talking style. Even people's voice became more confident in the formal and professional atmosphere.

Choosing a job also means choosing a group of people you work with. Politicians choose to advocate for the public and work with a group of public figures. Sales people work with business managers or factory producers. Faculties of universities work with the smartest group of contemporaries and younger generations. If a person wants to be a professional athlete, he/she has to go to professional schools and take specific training with the same profession of people. If a person wants to be an artist, he/she has to be exposed to the musical or visual arts and learn the skills first. The groups of people are the basic elements of people's social network.

\subsection{The Choice of Work}

People choose different works. Sales people conquer accounts to make volume increase; lawyers assist business people to complete transactions and solve disputes by using legal methods; scientists use experiments to testify presumptions and create new theories; doctors master advanced technologies and use medicines to cure diseases, etc. What is the standard for choosing an occupation? Do people focus on a specific area according to their talents or interests, or just according to the market needs? The answers are diverse.

Change is difficult for a person to make. The older a person is, the harder a change is to make. Due to this phenomenon, one had better decide his/her career path when he/ she was young. However, it is hard to make a decision without experience. A slogan in China says, "one will not know what is good until he tastes the good one." Imagination is far away from practice, especially for student just graduates from school. Even though change is hard, change is possible. Only if one is open-mined and hard-working, to look outside and fulfill the gap between the current occupation and their dreams, change could be made.

\subsection{Gap Year}

In some universities, graduate students do not directly pursue a higher degree or go to work, but choose to leave their ordinary path for a period, which is called the "gap year". This is more prevalent in China in recent years, which will help students to make a wiser career development choice.

Graduate students choose to travel or apply for an internship to take a break from 
normal school life. They use this time to open themselves to the world that they usually know but never "waste" time to conceive since they were eight years old. In this circumstance, they are free to experience a controversial or opposite part of life, to be a person they never had opportunity to be. Sometimes during this divergent change of the role, they will be closer to their own interests and listen to the voice of their hearts.

In Wikipedia, gap year is "an expression or phrase that is associated with taking time out to travel in between life stages." It is also known as sabbatical, time off and time out that refers to a period of time (not necessarily 12 months) in which students disengage from curricular education and undertake non curricular activities, such as travel or work. Gap year is most popular among individuals who have finished high schools and intend to commence tertiary education.

\section{Something Borrowed}

When choosing a work, people choose a life style. Professions mold people's characters, more or less, consciously or unconsciously. Legal professionals use analytical methods to solve problems and live in a legal empire. However, artists and self-employers live a less regular life, whose schedules are more flexible and living styles are more casual. Sometimes the "should be" life may not be the one a person really "wants".

In the novel Something borrowed (Giffin, 2005), the heroine, Rachael, is a female lawyer who graduated from NYU law school and started legal career as a lawyer in New York. She had a feeling on her law school classmate and good friend, Dex. She never had courage to tell him even Dex dated her several times. Dex also had a strong feeling on Rachael, but he is so good a student who follows his parents' will all the time of his life. He always does things he "should" do, but not he "wants" to do. During a date, Dex asked Rachael for a dinner but Rachael brought her close friend, Darcy, a party animal. Dex was attracted by Darcy's outgoing personality and relaxing style and they fell in love fast in the red wine atmosphere. Rachael left the bar and cried alone, but when Dex ran after her and asked what happened, Rachael smiled and pretended to be easy. Dex thought Rachael had no feeling on him. He then dated with Darcy and they got engaged.

In Darcy's 30 years old birthday party, she announced the news that she and Dex are engaged. During that night, Rachael drank a lot and told her disguised feeling to Dex. In an occasional second, they remind each other the spark they used to have in law school. They betrayed Darcy. This story was dramatic after they broke the moral baseline. They are both lawyers with ethical consideration. However, they cannot stop thinking of each other. Dex and Rachael wandered around each other's heart, moving forward and backward, between friendship, love, and colleague relationship. Dex finally destroyed his promise to Darcy, and followed his heart to marry Rachael.

The reason I discuss about this novel is because choosing a job is like a romance relationship. Some people choose to live an easy life and a slow pace. However when they bump into an energetic, passionate working style, they cannot stop thinking about change. Identically, those who live in a financial empire, wearing LV, Gucci or Chanel 
may be jealous of the couch potatoes. One never knows which is better for him/her without experience. Time is limited, even people cannot experience all kinds of life; they may select the most important one according to the real voice of one's heart.

\subsection{Gaining Happiness}

Aristotle stated: "We are what we repeatedly do. Excellence, then, is not an act, but a habit." By working people fulfill their economic and social needs, exert their god given potential and create values. Pursuing for survival and development may be the intrinsic value of work, which encourages generations to strive. Delving deep into the miracle ocean of work helps us better understand of what makes a good life.

What is your goal? You can not define what is good, but maybe you know what is bad. For Einstein, maybe one of his goals is to know the general relativity, the other goal is to discover the general relativity. The goal could be that someone should have known this. But the goal also could be that he wishes to know the theory. For most normal people, working for money to earn a decent life is more important. However, once one gets enough money, what is the purpose for the next level of life? Desire is endless.

In Protestantism Ethic and the Spirit of Capitalism (Weber, 2012), Weber stated, "Remember that time is money. He that can earn ten shillings a day by his labor, and goes abroad, sits idle, one half of that day, though he spends but, sixpence during his diversion or idleness, ought not to reckon that the only expense; he has really spent, rather thrown away, five shilling-, besides." "Remember, that credit is money. If a man lets his money lie in my hands after it is due, he gives me interest, or so much as I can make of it during that time. This amounts to a considerable sum where a man has good and large credit, and makes good use of it."

"Remember, that money is of the prolific, generating nature. Money can beget money, and its offspring can beget more, and so on. Five shillings turned is six, turned again it is seven and three pence, and so on, till it becomes a hundred pounds. The more there is of it, the more it produces every turning, so that the profits rise quicker and quicker. He that kills a breeding sow, destroys all her offspring to the thousandth generation. He that murders a crown, destroys all that it might have produced, even scores of pounds."

"Remember this saying, The good paymaster is lord of another man's purse. He that is known to pay punctually and exactly to the time he, promises, may at any time, and on any occasion, raise all the money his friends can spare. This is sometimes of great use. After industry and frugality, nothing contributes more to the raising of a young man in the world than punctuality and justice in all his dealings; therefore never keep borrowed money an hour beyond the time you promised, lest a disappointment shut up your friend's purse forever."

In fact, "a good professional must be a good human being." The word "professionalism" covers the working ethics, which restricted the aggressiveness in a capitalized world. Work ethic is how one gets along with others, the attitude, behavior, respect, communication, and interaction. Virtues such as honesty, integrity and accountability 
are important for a worker to live a good life.

\subsection{Hunting and Accumulation}

In China there was a novel called Fortress Besieged (Qian, 2004). In this book the author Qian Zhongshu draw a big picture of the traditional intellectuals. The subject is everything we expect, is like a fortress besieged, the insiders want to get out, however the outsiders want to get into it. Work is also like this fortress besieged. Every job has its merits and disadvantages, a person should know what he wants when making the choice. Ask yourself, "what is the most important thing? Then that is "good" for you. A man's meat is another man's poison.

Capitalism is about accumulation, including interpersonal relationships, experiences, social networks and reputations. If a person change his/her career path too often, the accumulation is hard to establish.

Equity is relevant; opportunities are not fair to everybody. Not every tiny effort has the gain, and not every insistence will be seen. Trust is hard, understanding is also difficult. But all we can do is to be patient and keep waiting. Every successful man has experienced the pale winter. Only after enduring the long and cold season, spring will come. Frustration appears usually. Look what you have got is more important than expecting the objectives beyond. Be content will make a person grateful for the god given potentials and seize the talented future. Normal and boring steps lead to the grand scenery. Adverse circumstances select the ones with courage, endurance, passion and audacity of hope.

\subsection{Balancing Work and Life}

Is spiritual and substantial happiness obtained simultaneously? Max Weber observed: "One person is naturally responsible, which is a representative of the social ethics of Capitalism society." Do people get happiness or sadness during careful work? In Kant's theory (Kant, 2008), this kind of happiness is obtained beyond the body feeling, however, in Chinese Ming Dynasty, the philosopher Wang Yangming mentioned "Zhixing Heyi" (Henke \& Tufts, 2010), which means that the body is triggered by the intellectual discovery and improvement. Practice and knowledge cannot be separated but is progressed at the same time.

We work to live, but not live to work. Work is a part of life. If the life is not harmonious, work is not on the track. Training and exercising is important, family and social communications are also significant for a good worker. The most important thing is happiness. Psychologists conclude that the people gain happiness mostly from work. The sense of achievement and the ability to make influence on others gives a person countless satisfaction. The happiness of work will make one person more confident, gentler, and more elegant.

\section{The Perfect Mile}

Work is like a sport, only endurance and persistence helps an athlete to meet the para- 
mount. I was immersed in the book The Perfect Mile: Three athletes, one goal and less than four minutes to achieve it (Bascomb, 2005). In 1952, three world-class runners set out individually to break the barrier and to challenge the human extreme. They are Roger Bannister, a young English medical student; John Landy, the privileged son of a genteel Australian family, who trained relentlessly in an almost spiritual attempt to shape his body to the single task; Wes Santee, the swaggering American, a Kansas farm boy who believed he was just plain better than everybody else.

The three challengers have different backgrounds and represent different kinds of people doing track and field sport. In a broader context, they represent different groups of people doing sport. This represents the spirit of sport-combine people from different culture, different educational background, different life value, to the same track. This is also the unique merit of sport-no discrimination of gender, race, and wealth.

The spirit also applies to work context. When successful workers share their experience, they share a common value-the "spirit" - to struggle for dreams and never, ever give up. Demonstration and perseverance is the key point of success, which is admirable. The competition is cruel but fair.

\subsection{The Right Instructor}

God is fair. Almost $20 \%$ people own the $80 \%$ wealth; however they do the $80 \%$ works. Successful people are a small group, but they have common virtues. Their paths cannot be cloned, but the merits can be learned. Even time has changed and the old people are out of fashion, in one's life they will meet the similar dogmas and the precedents have plenty of experiences. Communication with the people stronger and older than you will broaden the perspective and make one wiser. Sometimes we know the result, but we have to repeat it again and again. Changes may occur during the repetition process.

Just like a sport coach is significant to an athlete, the most important thing of a person starts working in his/her twenties is to follow a good instructor. In universities and graduate schools the knowledge is static, while in practice one could learn the practical experiences from instructors. For example, in the court, a judge is sophisticated and familiar with the dynamic cases, the adversarial trial practices, and the structure of judgments. A green hand should learn from zero. In law firms there are also senior associates who will teach and assist the junior associates with diverse issues upcoming. To drafting a contract, to negotiate, to meet clients and to provide persuasive legal opinions require not only the technique taught in law school, but the interpersonal skills and communication arts. These intangible virtues should be taught by the instructor.

The culture of an enterprise is also influential. One will learn the basic working ethics during the first job, in the work environment. Choosing a big platform is significant, since in large stages the directors are more qualified, and the actors and actresses are more well-trained. A standardized management and detail-oriented culture will help a starter establish good working habits.

\subsection{Legal Career for Myself}

As for myself, I pursued a law degree and wish to work with a group of elites. In the 
University of Michigan, I immersed in the grand library of the law school to absorb the precedent's wisdom. I talked with professors, judges and lawyers to get to know them. We shared the same legal "language" and wisdom.

Aristotle once observed that law is reason free from passion. However, in my understanding, law is passion out of reason. I made the resolution to contribute to the preservation of justice in my early adolescence. Throughout the years, a strong passion has driven me on my way to realize this dream. In law schools, I tried hard to learn more knowledge to broaden my perspective and do projects to explore deeper questions. In the court, I work sincerely, dealing with civil and commercial retrials and find to give the parties justice.

In the future, I would like to succeed as a judge with a particular focus on financial and commercial law. I have the dream that one day I will be alongside with those brave judges who came before me and who are honored for their graceful work in practice, flourishing independent thinking, and nourishing innovative spirit. I wish to be a striving law practitioner whose determination surpasses legal practice, a scholarly lecturer whose intellectual life mixes candor and hope, an upright idealism whose justified ideas will be recognized by conscious citizens, and an accountable realism whose rational concern that is respected through the united generation.

\subsection{Be Yourself}

In one of my favorite movies, "Dead Poets Society", there is a famous poem:

I went to the woods

because I wished to live deliberately, to front only the essential facts of life,

and see if I could not learn what it had to teach,

and not, when I came to die

discover that I had not lived.

Work unfolds us a path to understand the world. By working, people communicate with the environment and the society. They learn from each other and collaborate with each other. They compete with each other, and respect each other. In Hugo's novel The miserable world there was a famous statement, indicating that one is dignified because he/she lives a happy life. Everybody is deserved a good life. The good is achievable to everyone in the universe. There is no perfect life, but a proper and comfortable path to happiness.

People live in the world with dream, passion, pursue of knowledge and love. One cannot decide the parents, the family and the environment of growth, but he/she can decide what kind of person he/she wants to be. Work offers this opportunity for a person to choose the life he/she wants. What is the real need for one person? What is the music of one's heart? Only the person him/herself knows. How to approach to the bottom of one's heart? There is an experiment. Keep silent, and forget all the knowledge and information taught by others. Write a list of the things you want to do, keep writing, and keep thinking, until the one triggers your tears, making you cannot stop crying 
from the bottom of the heart.

Sisyphus has a boulder to roll. For rational people, this may be a punishment. But for him, this is the process of gaining spiritual freedom. Work is like this rolling. I believe only by practicing and experiencing will one reaches the deep feeling of good life.

\section{Conclusion}

Life is neither an experience machine nor a heroine experiment, but real and substantial. "The Hungry Ocean" told us about the reason, value and compensation of work. "The Devil Wears Prada" taught us dramatic changes would appear when you chose a job. Thus "Gap Year" is necessary for a student to have plenty of time to think about the career path. "Something Borrowed" is a great story of finding what you really want. Sometimes we gain happiness by repetition and accumulation. It is a necessary to keep a balance between work and life. "The Perfect Mile" helps us set up a goal and be ourselves. Good instructor is also important.

I would like to end this paper with the impressive remarks by Steve Jobs, "Your time is limited, so don't waste it living someone else's life. Don't be trapped by dogmawhich is living with the results of other people's thinking. Don't let the noise of others' opinions drown out your own inner voice. And most important, please have the courage to follow your heart and intuition. They somehow already know what you truly want to become. Everything else is secondary." (Steve Jobs, 2005).

\section{References}

Bascomb, N. (2005). The Perfect Mile: Three Athletes, One Goal and Less than Four Minutes to Achieve It. Mariner Books, Reprint Edition.

Giffin, E. (2005). Something Borrowed. St. Martin's Griffin.

Greenlaw, L. (2000). The Hungry Ocean: A Swordboat Captain's Journey. Hachette Books.

Henke, F. G., \& Tufts, J. H. (2010). The Philosophy of Wang Yang-Ming. BiblioLife.

Kant (2008). Critique of Pure Reason. Penguin Classics, Revised Edition.

Qian, Z. (2004). Fortress Besieged. New Directions.

Steve Jobs (2005). You've Got to Find What You Love, Jobs Says. http://news.stanford.edu/2005/06/14/jobs-061505/

Taylor, A. E. (2012). Aristotle. Dover Publications.

Weber, M. (2012). Protestantism Ethic and the Spirit of Capitalism. Create Space Independent Publishing Platform.

Weisberger, L. (2004). The Devil Wears Prada. Broadway Books, Reprint Edition. 
Submit or recommend next manuscript to SCIRP and we will provide best service for you:

Accepting pre-submission inquiries through Email, Facebook, LinkedIn, Twitter, etc. A wide selection of journals (inclusive of 9 subjects, more than 200 journals)

Providing 24-hour high-quality service

User-friendly online submission system

Fair and swift peer-review system

Efficient typesetting and proofreading procedure

Display of the result of downloads and visits, as well as the number of cited articles

Maximum dissemination of your research work

Submit your manuscript at: http://papersubmission.scirp.org/

Or contact ojpp@scirp.org 